\title{
T. H. Huxley's Evolution and Ethics: Struggle for Survival and Society
}

\section{Klára Netíková ${ }^{1}$}

Abstract: The present paper focuses on main points of Thomas H. Huxley's lecture 'Evolution and Ethics', which addressed current social and political debate about application of evolutionary principle of competition on society. Huxley, a well-known proponent of Darwin, was strictly opposed to such application as he threatened that ethics, the base of civilized society, would disappear. He claimed that ethical process kept natural processes under control and made men truly human. He stressed that while evolution governed the biological realm of nature, ethics was domain of human conscience and society.

Even though Huxley was well established scholar, ideas of his contemporary colleague Herbert Spencer often gained much more popularity amongst general public. This was certainly true in China, where Spencer's evolutionary ethics gained tremendous popularity. The Theory of Evolution in China was immediately dragged into debate about national survival. Spencer's thought was paradoxically introduced to China by translation of Huxley's critical lecture 'Evolution and Ethics'. Chinese intellectuals were, however, far more interested in the concept of struggle and competition than in philosophical questions about meaning of ethics in human society, which troubled Thomas Henry Huxley in his public lecture presented in 18th May 1893.

Keywords: evolution, ethics, social darwinism, Huxley, China, Yan Fu.

\footnotetext{
1 Institute of East Asian Studies, Faculty of Arts, Charles University, Celetná 20, 11642 Prague 1, klaranetikova@yahoo.com
} 


\section{Introduction}

$19^{\text {th }}$ Century Europe was largely influenced by an immense idea of the Evolution Theory. Before Charles Darwin (1809-1882) published his version of evolutionary theory in his Origin of Species in November 1859, the concept of evolutionary change or progress was already present in European geology and biology. Even though Darwin himself was very hesitant when it came to the application of any evolutionary theory to humankind, the concept was dragged almost immediately to the old discussion about society, civilization, men and nature. As new scientific knowledge and theories emerged, the traditional Christian view of the world was tremendously changed: before, the general inclination of thought bent towards existence of a harmony in nature, nevertheless with deeper understanding of natural and physical laws, this picture was drastically changed. It seemed more likely that reality consisted of competition and struggle for existence. The general rule of the world was thus power and strength and men themselves started to be understood within this natural world of endless competition for survival and progress. Humans were fully subordinated to all natural laws, no different from any other species on the planet, only more evolved, but still bound within the same principles. With such an understanding new range of questions arose, amongst these the biggest one was undoubtedly problematic of human ethics and morality. How did human moral standards fit into evolutionary theories? Was there a difference between natural world and 'higher' human civilization? Was ethics a natural development any species could evolve too, or was it something specifically unique to humankind? Where was mutual help and altruism in the world now perceived as a rough competition for might? The relationship between ethics and natural struggle for existence attracted attention of many distinguished $19^{\text {th }}$ Century scholars: hugely popular Herbert Spencer (1820-1903), Darwin's fervent proponent Thomas Henry Huxley (1825-1895), British sociologist Benjamin Kidd (1858-1916) and many others were focusing on ethics and morality within society.

British sociologist and philosopher Herbert Spencer is most known for his application of evolutionary principles to men and society. He created an 'evolutionary ethics', which was later commonly and very vaguely addressed as 'social Darwinism'. By treating society as a living organism, he subjected civilization to the same laws within which individual organisms evolve - competition, fitness and progress towards higher forms. His ideas that everything on Earth evolves from simple to complex, from lower to higher and that there is a final aim of the evolution were tremendously popular. They shaped not only European perception of the world, but they had a massive impact on Chinese and Japanese intellectuals at the turn of the $20^{\text {th }}$ Century. In his writings Spencer stated that 'natural progress' cannot be artificially forced and that each individual should push his strength to the utmost in order to achieve success not only for him, but to all society. There was a common belief in Victorian Britain, that every individual had a potential to achieve success and that being successful meant strengthening of all society. ${ }^{2}$ Spencer's conception of evolutionary ethics, although admired by many, was however not appealing to everyone, amongst the opponents, one of the most significant thinkers was T. H. Huxley.

Thomas Henry Huxley disagreed with Spencer at several points. He stressed ethics and morality as the key characteristics of humankind, not the ability to compete. He declared that even though ethics was derived from natural laws and cosmic processes, it was in fact in an opposition to them; it was a restriction which fought against the natural law of struggle for

\footnotetext{
${ }^{2}$ This idea was behind such successful publications as by Samuel Smiles: SMILES, Samuel. 1968. SelfHelp: The Art of Achievement Illustr. by Accounts oh the Lives of Great Men. London: Sphere Books.
} 
existence. Ethics and sympathy in human society were, in short, the essence of humanity. Huxley did not wish to leave moral consciousness of each individual to the idea that his success would be a natural proof that his actions were also right. To show his own perspective and disapproval for Spencer's concept of ethics, T. H. Huxley delivered a public lecture at Oxford in 1893 about the importance of ethics and morality in human society. This lecture was later published and provided with an introductory explanatory essay.

The present paper focuses on Huxley's perspective of human society and on his perception of the relationship between the struggle for existence and ethics in society. To what extent, according to Huxley, could humans be self-interested, abiding by the harsh rule of survival and one's own benefit? Could ethics and morality, even altruistic behaviour, cooperation and support, be of any benefit to the society in the light of the presumption that only 'the fittest' would and should survive? How did Huxley and Spencer's conceptions influence China? How did China, pressed by the imperialist powers to grant concessions and forcefully divided into zones of their influence, ${ }^{3}$ respond to the concept of evolution? The essay is using mainly Huxley's essays Evolution and Ethics and Prolegomena and other literature such as Bowler's Evolution: History of an Idea or Benjamin Schwartz's In Search of Wealth and Power: Yen Fu and the West.

\section{The Meaning of Ethics in Society}

Huxley's public lecture Evolution and Ethics, delivered at the Sheldonian Theatre in $18^{\text {th }}$ May 1893, was part of newly established public events in Oxford called the Romanes Lectures. The Romanes Lectures were named after their founder, biologist George John Romanes (1848-1894), who was also a friend of Darwin. The year of 1893 was just the second year since they started to provide the public with interesting topics about science, art and literature. T. H. Huxley was one of the first to present his paper at this prestigious occasion, which continues to this day.

As a keen proponent of Darwin and a figure largely responsible for the overall acceptance of Darwin's evolution in the Victorian Great Britain, Huxley used this lecture primarily to oppose Spencer's evolutionary ethics and against the use of biological evolution in the field of social ethics and policy. The lecture was also indirectly aimed against political interpretation of evolutionary selection, which served as a scientific support for imperialist policy. ${ }^{4}$ As the meaning of the lecture was hard to understand, when it came to its publishing, Huxley equipped it with an explanatory introduction. In this essay, he clearly distinguished that nature and society were ruled by generally different laws - nature was governed by natural (survival) laws, while society by ethical order, which ensured that natural laws would not govern interpersonal relations. Society, he expressed, no longer adapted to the environment (nature), but similarly as in the artificially-created garden people shaped nature according to their needs and most of the cosmic processes were kept under control. The artificial garden and human society were thus both within (biologically) as well as outside (through skill and intelligence) of the evolutionary

\footnotetext{
${ }^{3}$ For further readings see OTTE, Thomas G. 2007. The China Question: Great Power Rivalry and British Isolation, 1894-1905. New York: Oxford University Press.; SCOTT, David. 2008. China and the International System, 1840-1949: Power, Presence, and Perceptions in a Century of Humiliation. Albany, NY: State University of New York Press. or SCHRECKER, John E. 1971. Imperialism and Chinese Nationalism: Germany in Shantung. Cambridge, MA: Harvard University Press.

${ }^{4}$ For further reading, see HELFAND, Michael S. 1977. "T. H. Huxley's 'Evolution and Ethics': The Politics of Evolution and the Evolution of Politics." Victorian Studies 20 (2): pp. 159-77.
} 
process. ${ }^{5}$ As we will observe in detail below, Huxley stated that the current scientific knowledge could not be applied on society as ethics was not based on natural laws.

It might seem somewhat surprising that Darwin's fervent proponent was actually against the use of biological evolution on human society. For Huxley, such application posed several threats: it led inevitably towards moral rating of progress, which would further lead to society not based on ethics, but on success in competition only. It, as Huxley feared, could mean casting away moral standards, which at initially helped to bring civilization (and mainly British one) to its glory.

\subsection{The Threat of Ethical Estimation of Nature}

Huxley disagreed with Spencer's idea that biological evolution always brought higher and better states of existence. He also refused the concept that the progress was inevitable. Huxley was relying on Darwin's evolutionary concept, in which stagnation and degradation of species were plausible. There was no certainty of progress towards higher forms within Darwin's evolutionary theory. ${ }^{6}$ This, as Huxley stressed, meant that the natural principles could not serve as an ultimate guide towards higher and better states of humankind. The key observation, which led Huxley to oppose evolutionary ethics, was the difference between perception of right and wrong from natural (biological) point of view and from human ethical perspective. What was or could have been considered successful and therefore right in the biological survival of the fittest, was often perceived as a crime in the human society. The perception of good and evil depended on moral judgement of men. As Huxley expressed, to humankind wolf seemed as utter evil, while mild deer as pure innocence, but in the eyes of nature, neither was moral nor immoral. Deer was equipped with the ability to flee, the wolf with the ability to catch prey. People applied moral standards on their behaviour; ethics was not part of the natural realm, which in fact treated both as equals trying to survive in harsh wilderness. ${ }^{7}$

Ethical behaviour and natural competition were consequently two contradictory processes. And because men had both biological nature as well as ethical standards of behaviour, these two clashed within everyone. Huxley stressed that the 'mere animal' in man was struggling for existence as any other species on the planet, neither moral nor immoral, and the man as a member of society was on the other hand an ethical moral being, sympathetic to one's fellow citizens and society. Ethics in society was a restriction to the self-interest and competition amongst individuals; it was much more than social cooperation of animal packs and herds, from which it grew. What distinguished human society from packs of animals were human selfawareness and motivations. While bees, stated Huxley, created very efficient successful social group, their actions were without any conscious motivation. Neither selfish, neither unselfish, it was a simple development of mechanical natural process. People, on the other hand, were driven also by moral responsibilities towards others. Seeing ethics as such important part of society, Huxley deemed evolutionary ethics of Spencer as unacceptable. To make his case, he criticised Greek Theodicy and Indian Cosmodicy; but he was ultimately and indirectly aiming

${ }^{5}$ HELFAND, Michael S. 1977. "T. H. Huxley's 'Evolution and Ethics': The Politics of Evolution and the Evolution of Politics." Victorian Studies 20 (2): pp. 173-174.

${ }^{6}$ In the letter of 1862 addressed to Charles Darwin, Huxley praised the Evolution Theory mainly for the reason, that it allowed the idea of a certain organism not developing throughout vast period of time (a 'standing still' state) or even degenerating. See BARTHOLOMEW, Michael. 1975. "Huxley's Defence of Darwin." Annals of Science 32 (6): pp. 525-35.

7 See HUXLEY, Thomas Henry. 1894. "The Struggle for Existence in Human Society." In Evolution and Ethics and Other Essays. London: Macmillan and CO. pp. 195-236. 
on Spencer's evolutionary ethics. All of them were, in Huxley's eyes, overlooking ethics as the essence of human society.

\subsection{The Threat of Metaphysical Explanation of Suffering in Nature and Society}

The transmigration theory of Indian Cosmodicy, very much like Spencer's evolutionary ethics, meant for Huxley that everyone was responsible for one's own actions. And as only one's conscience and knowledge could ensure one's better life, it created selfish self-interested men. It was a system which bade 'men look to nothing but their own efforts of salvation' ${ }^{8}$. It promoted individuals who rather ignored all good in the world in order to escape from possible evil and suffering - in other words, Huxley saw it as the poor obsolete philosophy, which gave up the fight against evil.

As far as the Greek philosophy was concerned, it did not face the problematic of evil and ethics in Huxley's eyes much better. Greek philosophy of Stoicism as well as Christianity did not accept the existence of natural evil in the world. If there was any evil and suffering in the world, it was caused by men's action and it could have a disciplinary value. Christianity also stated that there could always be some hidden good within. Huxley acknowledged that there could indeed have been sometimes 'a soul of good in things evil' and that pain and sorrow could have a disciplinary value, but the reality undeniably showed that there was a lot of suffering uncaused by any crime and without any disciplinary value. According to Huxley, both Stoicism and Christianity missed the basic truth that the evil 'existed' only because of human moral standards, which enabled men to understand certain behaviour as right or wrong. Ethics was not present in the natural world itself; it was present in the conscience of humankind. Huxley criticised evolutionary ethics of Herbert Spencer because it was incompetent to furnish any better reason why what we call good is preferable to what we call evil."

It was, however, not only Spencer's idea that there was some basis for morality in nature. Huxley also had to challenge the common belief of the Victorian Empire that everyone was responsible for his state of life. In this respect, it was believed that pauperism manifested only a lack of character and laziness. It was not a social problem, but a proof that poor people were weak and unfit to compete for better individual social status. Consequently, they were rightfully punished by falling to the bottom of society. This oversimplification may seem audacious now, but it was a general belief of the time that everyone had opportunity to improve one's life. And with enough hard effort, success was inevitable. ${ }^{10}$

\subsection{Threat of Extreme Self-assertion and Self-restraint in Society}

Herbert Spencer also linked individual success with the success of all society. Spencer, not a Darwinist, but a Lamarckist, stressed the influence of environment on an individual organism - once organism changed according to the environment, it became successful and passed down its success to the future generations (for a Lamarkist, there was no difference between inherited and acquired qualities). English tradition of utilitarianism and politics of laissez-faire led Spencer to believe that one's success was often an undeniable proof of righteousness of one's actions. Spencer was by no means unethical, but he saw the roots of ethics elsewhere than

\footnotetext{
${ }^{8}$ HUXLEY, Thomas Henry. 2015. Evolution and Ethics. London: Forgotten Books. p. 21.

${ }^{9}$ Ibid., p. 31.

${ }^{10}$ For further readings see FREEMAN, Derek. 1974. "The Evolutionary Theories of Charles Darwin and Herbert Spencer." Current Anthropology 15 (3): pp. 211-37.
} 
Huxley. Huxley saw 'no point in following nature's harsh methods, ${ }^{11}$ as there was no evidence of morality in nature. But Spencer believed that nature gave basis of morality to man as well as restrictions to human self-assertion - and that a decent pressure on individuals could bring the best of them.

Spencer's ideas were unacceptable for Huxley because, in theory, they tended to treat selfinterest as ultimately more important than selfless ethical approach towards others - even though Spencer himself did never cast away ethical (and altruistic) behaviour, it was simply not in the core of his philosophy; natural laws occupied that place. They guaranteed reasonable amount of altruism and sympathy in society. For T. H. Huxley, modern civilization already overcame many laws of nature and even though ethics was an outcome of the evolutionary process, it evolved to something so unique that nature had no longer control over it, neither it had any means how to ensure that 'good' (as understood in society) would prevail. While ethics was part of natural process in Spencer's philosophy, for Huxley, it was already well outside of any biological natural realm. Why indeed, asked Huxley, would people violate their 'deepest sense of moral responsibility to others, to follow the dictates of a natural system that is without meaning? ${ }^{\prime 2}$ Humanity had to abide by ethics in spite of the cosmic laws, not according to them. It was ethics and morality, restrictions of one's self-interest, what made men really human and what made society a true and moral modern civilization.

There was still an animal in man, which fought for one's own benefit with no sense of ethics, but it was deliberately suppressed in human civilization. Society was supposed to constantly fight against the inner non-moral nature, which would allow unrighteousness if not checked by human moral conscience as 'the thief and the murderer follow nature just as much as the philanthropist'. Huxley attributed the problematic approach towards good and evil in evolutionary ethics to the common misunderstanding of term 'the fittest' in the phrase survival of the fittest. Spencer's phrase survival of the fittest was often understood as survival of the best in the moral sense. According to Huxley and Darwin, 'the fittest' meant biological adaptation without any moral connotation; in other words, what could be called 'the fittest' in nature depended upon natural conditions. Biological evolutionary process within the society would ensure that those best biologically adapted would survive. Ethical process within society (often achieved by laws and order) on the other hand did not mean survival of the fittest in biological sense, but the survival of those who were 'ethically the best' ${ }^{13}$

Huxley stressed that in reality 'the fittest' in the society were not those who were at the peak and the weakest were not necessarily those at its bottom; 'the fittest' were those who formed the body of society, the most numerous part of society, those 'moderately' fit, neither on the peak, nor at the bottom. Thus, reasonable self-restraint as well as moderate self-assertion led society to its success. The ideal of every man was 'to limit his freedom of action to as there in which he does not interfere with the freedom of others'. ${ }^{14}$ Huxley saw mutual relationship not just between individuals within one group, but also between one individual and whole group everyone had a 'duty to the community, to the protection and influence of which he owes, if not

${ }^{11}$ BOWLER, Peter J. 1984. Evolution, the History of an Idea. Berkeley: University of California Press. $p$. 221.

12 Ibid., p. 244.

${ }^{13}$ HUXLEY, Thomas Henry. 2015. Evolution and Ethics. London: Forgotten Books. p. 33.

${ }^{14}$ HUXLEY, Thomas Henry. 1894. "The Struggle for Existence in Human Society." In Evolution and Ethics and Other Essays, 195-236. London: Macmillan and CO. p. 205. 
existence itself, at least the life of something better than a brutal savage. ${ }^{15}$ Society enabled man to live a better life within modern civilisation and, in exchange, it rightfully required everyone to abide by its ethical standards and to moderate one's self-interest. Huxley strongly stood on the ground of ethics and laws as he preferred order to chaos. He similarly criticised exaggerated sympathy, which he saw in the concept 'do as you would be done'. According to this concept, Huxley said, robbed man would had to let the thief go as he, identifying with the thief position, would also want to be set free by the person, of whom he had stolen. Such unhealthy sympathy would bring a disaster similar to the one caused by unethical cruelty.

\subsection{The Threat of Artificial Selection in Society}

Huxley also did not want to apply the Theory of Evolution on society because of the idea of selection. This was an idea Herbert Spencer strongly disapproved of as well. However, while Herbert Spencer disapproval was based mainly on the scientific argument that the progress (of humankind) could not be artificially advanced, Thomas Henry Huxley argued through ethics and reason. Huxley argued that the abolition of the weak was not only ethically unacceptable in a civilized world, but the selection of man was more difficult because the process of man's development was more complex than that of for example cattle. Sometimes, man showed his best later in life or under certain conditions. Huxley warned that everyone could be perceived as weak and unfit at least once in his lifetime. Judging individuals through the current scientific knowledge was therefore impossible. Current society was able to judge individual's action (crime or good), but it was not able to predict who would be unfit and who would be strong. The sense of common moral standards enabled society and individuals to evaluate their own actions and judge them through moral conscience only one at the time: 'The conventions of honour bind men who break legal, moral, and religious bounds; and while people endure the extremity of physical pain rather than part with life, shame drives the weakest to suicide. ${ }^{\prime 16}$ Ethical standards of society made moderate pressure on individuals to behave within certain moral limits to the benefit all society.

Suffering in modern society was according to Huxley mainly caused by man's tendency to reproduce ('multiply') without restriction; and as this 'multiplication' led to the lack of basic necessities, struggle for existence could threaten society once again. The fear of overpopulation came from famous population theory of Thomas Robert Malthus (1766-1834). Huxley expressed his anxieties about overpopulation in a series of essays from late 80's and early 90's, assembled under the name Social Diseases and Worse Remedies. Within these texts Huxley continued to stress the ethical approach (mutual help and sympathy) and responsibilities of the individual towards society:

So that if society, having, quite gratuitously, done all these things to me, asks me in turn to do something towards its preservation - even if that something is to contribute to the teaching of other men's children - I really, in spite of all my individualist learnings, feel rather ashamed to say no. ${ }^{17}$

Ethical standards and sense of responsibility were in the core of Huxley's philosophy. Huxley understood ethical process and natural evolution as contradictory processes, where ethics kept

\footnotetext{
${ }^{15}$ HUXLEY, Thomas Henry. 2015. Evolution and Ethics. London: Forgotten Books. pp. 33-34.

${ }^{16}$ HUXLEY, Thomas Henry. 1894. "Evolution and Ethics Prolegomena." In Evolution and Ethics and Other Essays: pp. 30-31.

${ }^{17}$ HUXLEY, Thomas Henry. 1894. "The Struggle for Existence in Human Society." In Evolution and Ethics and Other Essays, 195-236. London: Macmillan and CO. pp. 230-231.
} 
cruel unethical competition under constant check. It was a balanced relationship between selfassertion and self-restraint, between the natural process and the ethical one which according to Thomas Henry Huxley were the key to flourishing.

\section{Evolutionary theory in China}

Due to European expansive policy of imperialism in $19^{\text {th }}$ Century, Chinese politicians and historians in the early $20^{\text {th }}$ Century often addressed the $19^{\text {th }}$ Century as 'the Century of Shame' (or 'Century of Humiliation'). ${ }^{18}$ Although China was never officially a colony, it did not avoid Western imperialism, which grew from categorization of cultures and nationalism. Humiliated by Western technological supremacy and wartime defeats, China soon started to purchase new technologies, study sciences and modern concepts, which brought Europe to such superiority. The most burning question for Chinese intellectuals was why did China fell behind so much and how could it rose to power and independence again. The answer was, surprisingly, found in the Theory of Evolution.

\subsection{Yan Fu and his Translation of Huxley}

The Theory of Evolution came to China mainly through Yan Fu's (1854-1921) translation and commentary of Huxley's lecture Evolution and Ethics and Prolegomena. Published in 1898, rather soon after the actual date of Huxley's lecture, it immediately attracted attention not only in China, but in Japan and other Asian countries as well. The translation was published under the title Tianyan lun, which could be translated as On Evolution (Yan Fu's term 'evolution' tianyan, unused in the contemporary Chinese, consists of two characters: 'Heavens' or at this instance 'Nature' tian and of verb 'evolve', 'develop' or 'change' yan). As the name of the translation itself suggests, the focus was driven to the concept of Evolution, not to Huxley's concerns about human ethics or morality. Yan Fu, in fact, deliberately overlooked Huxley's ethical concerns and focused instead on evolutionary concept itself and on Spencer's ideas he admired. Unsurprisingly, his commented translation did not promote Huxley's approach towards ethics, but Spencer's concept of society, which behaved like a living organism. Spencer's approach caught Yan Fu's eye as it offered explanation of imperialism and of Chinese defeats, but also a solution. ${ }^{19}$ With true understanding why China fell behind, she could finally grasp a chance and rise once more.

But why did Huxley's concerns about ethics did not appeal to Chinese audience at all? Huxley asked for ethics and morality, which might have been perceived as anti-imperialist. And antiimperialist approach would have indeed served Chinese cause... The answer could be found in the cultural background of the two civilizations; the traditional Chinese thought never saw a real dichotomy of man and nature as Christian Brits did. Yan Fu himself looked for the prescriptions for human behaviour in nature; he did not see the world of nature and man as essentially different and opposed to each other (as Huxley did): to Yan Fu processes of both were not separate. ${ }^{20}$ Huxley's worries about application of evolutionary concept of natural selection to society were not interesting enough for Chinese intellectuals. What they sought was

\footnotetext{
18 See SCOTT, David. 2008. China and the International System, 1840-1949: Power, Presence, and Perceptions in a Century of Humiliation. Albany, NY: State University of New York Press.

${ }^{19}$ See SHEN, Tsing-song Vincent. 2014. "Evolutionism through Chinese Eyes: Yan Fu, Ma Junwu and Their Translations of Darwinian Evolutionism." ASIANetwork Exchange 22 (1): pp. 49-60.
}

${ }^{20}$ SCHWARTZ, Benjamin I. 1964. In Search of Wealth and Power: Yen Fu and the West. Cambridge: Belknap Press of Harvard University Press. p. 109. 
a universal theory, a solution, which would help them understand the main principles of the outside world. With enough knowledge, they could be able to turn around the current state of affairs and rose to a powerful empire. But Huxley claimed that the Theory of Evolution is not an absolute universal principle; on the contrary, he wanted it to be applied only on the biological world of nature and such a narrow view was no appeal to his Chinese readers. Why to separate world of humans and world of nature, when both were inseparable? Why to exclude human society from basic natural law, which seemed to be well working everywhere?

The commented translation of Huxley's essays thus served mainly two aims: it was published in order to explain the basics of the Theory of Evolution, and in order to show positively its application to society. Attracted more to Charles Darwin and Herbert Spencer, Yan Fu did not accept many of Huxley's arguments. The translation was not a translation per se, but a critical evaluation, propagating often Yan Fu's own ideas. Yan Fu not only 'localized' many of Huxley's explanatory metaphors to Chinese environment, but he also explained many of the terms and concepts as he himself, not Huxley and sometimes even his favourite Spencer, understood them. The evolutionary theory in China was immediately understood in the terms of competition: the strong prevailed and the weak were at the bottom, rightfully crushed for being unfit. Yan Fu's translation stressed, influenced by Spencer, that societies and states behaved like living organisms and they were competing severely for the supremacy. It is almost shocking, to what extent did Chinese intellectuals, influenced by this idea, understood war and political losses of their own empire as a rightful punishment for state and social weakness.

Yan Fu nevertheless tried to offer his readers not only an explanation and solution to the burning questions of the time, but also comfort. He deliberately linked many Western ideas with traditional Chinese concepts. He used passages of ancient Chinese classics, the Book of Change, which dates back before $3^{\text {rd }}$ Century BC, or from the old text Laozi. This allowed Chinese readers to accept new ideas without much effort; but it also provided a comforting reassurance that China was not as far behind as initially thought - after all, basic concepts from modern evolutionary theory were in the core of Chinese culture already since ancient times. In this way Yan Fu linked the Western concept of evolution with the traditional concept of change $y i{ }^{21}$ With this analogy, the theory's base did not appear as absolutely foreign; it only put Chinese knowledge into new light, confirmed it and expanded it. Evolution, in short, was seen as compatible with traditional Chinese thought, in which every living creature was constantly changed in the permanent process of transformation. ${ }^{22}$ Such eclectic approach was chosen deliberately and pragmatically.

In a similar manner, Yan $\mathrm{Fu}$ re-considered the traditional Chinese concept of manbehaviour/state-of-nature relationship. According to Confucian belief, man's actions were always reflected in nature; if a man behaved unjustly, natural catastrophe occurred as natural world judged morality in human world. In short, there was a knowing and omniscient 'deity' of Heaven. Yan Fu was well-aware that the two concepts, evolutionary ethics and Chinese idea of man-behaviour/state-of-nature relationship, were not entirely same, but he saw the same foundation of the world perception. He modified the obsolete concept of omniscient Heaven according to evolutionary ethics. Nature was not knowingly morally evaluating human actions, but it had absolute control over human lives through struggle for survival. If man was not fit,

\footnotetext{
${ }^{21}$ WANG Tiangen. 2016. Spread of [Yan Fu's] Tianyanlun at the End of the Qing Dynasty and at the Beginning of Republic. Hefei: Hefei Gongye daxue chubanshe. p. 23.

22 LOMOVÁ, Olga. 2014. "Liang Qichao v roce 1902: Přeměna Číny v silný a moderní stát za pomoci nového myšlení [Liang Qichao in 1902: The transformation of China into a strong and modern nation with the help of new thought]." Český časopis Historický 112 (2): p. 214.
} 
the results would be his lost in the realm of nature and human society. There were thus still natural consequences to the moral behaviour of men. Evolution seemed to be well corresponding to traditional Chinese thought.

As Huxley's Evolution and Ethics focused primarily on ethical issues of the evolutionary theory, Yan Fu partially addressed it as well. Huxley understood ethics as boundaries to the cosmic process; but Yan Fu, in his commentary, praised Spencer and claimed that ethics should be subordinated to the evolutionary process. If ethics was above natural selection, Yan $\mathrm{Fu}$ expressed his worries that those unfit would weaken all society in China. In the eyes of nature, everyone was equal and everyone was able to raise or fall. Different national experience made Yan Fu stressing what Huxley disagreed with. China was perceived as a dying country and struggle between individuals and between nations was not seen as unethical, but as a simple reality. Competition between nations, who behaved like living creatures, explained why China was losing. Its people were not fit enough, the whole country was not fit enough to successfully compete on the international field, but that could be changed if Chinese accepted the idea of struggle as the key characteristic of social and international dynamics. If people became strong, so would the society and the state. Yan Fu and his Chinese colleagues saw tempting universality of the evolutionary theory; it was a supreme law, in which everyone and everything was equal and all could progress towards higher states of being (or fall behind). ${ }^{23}$ For Yan Fu, same as for Huxley and Spencer, ethics played significant part in social development, but it was understood differently: there was no time in China to focus on those who fell behind. Competition was not to be dismissed as unethical, Yan Fu wanted to embrace it and use it to the benefit of Chinese national survival.

The idea that human world could be perceived as subordinated to the same laws of competition as the world of nature (so-called social Darwinism) became extremely popular in China. Yan $\mathrm{Fu}$ was largely responsible for its acceptance. However, even though Yan Fu acknowledged that cosmic rules were applicable to society, he did not support Spencer entirely. He instead agreed with Huxley that men should compete with nature as nature should always be governed by men. He opposed Spencer's idea of letting nature take free reign in human society without much intervention from man's part. ${ }^{24}$ Spencer supported individual's self-assertion, because he saw natural limits to one's selfishness. Yan Fu did not fully commit to this approach - for a Chinese intellectual, giving individuals such amount of freedom was far too scary. Society was to be governed, not let to govern itself. Although society was fundamentally no different from natural world, Yan Fu wanted it to be controlled, not left to hands of natural laws and processes. It is interesting that Yan Fu saw an analogy between Huxley's critics of Spencer and the philosopher Xunzi ( $3^{\text {rd }}$ Century BC), who criticised influential Confucian Mengzi ( $3^{\text {rd }}$ Century BC). Xunzi stated that nature was no school of virtue, thus opposing Mengzi. ${ }^{25}$ To summarize, Yan Fu stressed competition as well as order and sympathy (empathy) in society, he wanted limits to both of these principles, none of which should prevail.

\footnotetext{
${ }^{23}$ SCHWARTZ, Benjamin I. 1964. In Search of Wealth and Power: Yen Fu and the West. Cambridge: Belknap Press of Harvard University Press. p. 102, 111.

${ }^{24}$ WANG Tiangen. 2016. Spread of [Yan Fu's] Tianyanlun at the End of the Qing Dynasty and at the Beginning of Republic. Hefei: Hefei Gongye daxue chubanshe. p. 35.

${ }^{25}$ See SCHWARTZ, Benjamin I. 1964. In Search of Wealth and Power: Yen Fu and the West. Cambridge: Belknap Press of Harvard University Press.
} 


\subsection{The Meaning of Sympathy in Society}

The reason for stressing sympathy was the answer to the question Yan Fu and other intellectuals asked after accepting competition as the most important force of life. They turned the attention to the means which made European nations' progress so immense. And, interestingly, even though competition was important, Yan Fu found answer in human tendency to socialize and find order and morality amongst people of one group. While for Spencer, it was mainly an individual who was responsible for progress, for $\mathrm{Yan} \mathrm{Fu}$, it was not as much an individual as the whole group. ${ }^{26}$ And what made group (society) strong were the tendency of humanity for 'grouping' qun (tendency to form groups, societies and nations) and the sense of human rights and freedom. ${ }^{27}$ As people inclined towards grouping, mutual sympathy and cooperation grew and the sense of freedom and rights seemed to be a powerful emotion, which made people wanting being part of the society and nation even more. Yan Fu therefore defined international space as the sphere of competition, while domestic domain as a place governed by self-restraint of individuals and by cooperation. ${ }^{28}$ What was important was not a man, an individual being, but a man within society, a member who cooperated with others for the greater good of all. And the success of Western societies was attributed to the mastery of this cooperation. European nations were perceived as united, strong and politically and socially active societies. For many Chinese intellectuals, competition was suddenly understood primarily as a principle governing international relationships and sympathy and cooperation as a principle governing mainly the nation. Sympathy, however, should never weaken society; Chinese population were to be given new freedoms and rights as well as responsibilities, which ensured that people would be willing to partially give up their own freedoms for the benefit of all. This thought was spread mainly by one of the most popular Chinese intellectual of the beginning of the $20^{\text {th }}$ Century Liang Qichao (1873-1929), who was himself hugely influenced by Yan Fu and his translations.

Liang Qichao further used another very influential Western thinker to create his conception of modern society based on the concept of evolutionary ethics. It was the British sociologist Benjamin Kidd (1858-1916), who largely shaped the Chinese conception of social Darwinism. There were two main appealing concepts in Kidd's approach for Liang Qichao and others: the first was the idea that without competition there was decline and degradation, and secondly, that man should not be selfish and the group (society) was ultimately more important than the individual. ${ }^{29}$ According to Kidd it was religion and faith what kept human selfishness under

\footnotetext{
${ }^{26}$ For further readings, see WANG Fansen. 1997. "Evolving Prescriptions for Social Life in the Late Qing and Early Republic: From Qunxue to Society." In Imagining the People: Chinese Intellectuals and the Concept of Citizenship, 1890-1920, Studies on modern China, 258-78. Armonk, N.Y: M.E. Sharpe.
}

${ }^{27}$ See PRICE, Don C.. 2004. 'From Might to Right: Liang Qichao and the Comforts of Darwinism in LateMeiji Japan. ' in FOGEL, Joshua A. (ed.). The Role of Japan in Liang Qichao's Introduction of Modern Western Civilization to China. China Research Monograph 57. Berkeley, Calif: Institute of East Asian Studies, University of California Berkeley, Center for Chinese Studies. pp 68-106.

${ }^{28}$ See also WANG, Tiangen. 2016. Spread of [Yan Fu's] Tianyanlun at the End of the Qing Dynasty and at the Beginning of Republic. Hefei: Hefei Gongye daxue chubanshe.

This division between internal and external domain also influenced popular Chinese journalist Liang Qichao, who promoted strength li, knowledge and wisdom zhi and sympathy (humanity) ren as key characteristics of the new Chinese citizen. Unsurprisingly, the first two were for the competition amongst nations, the last one mainly (but not exclusively) for the Chinese society itself. See HUANG, Kewu. 2003. "The Reception of Yan Fu in Twentieth-Century China." In China Reconstruct (reprint). Lanham: The University Press of America. p. 66.

${ }^{29}$ For further readings, see LOMOVÁ, Olga. 2014. "Liang Qichao v Roce 1902: Přeměna Číny v Silný a Moderní Stát Za Pomoci Nového Myšlení.” Český časopis Historický 112 (2): p. 205. 
control. Interestingly, many Chinese scholars at the turn of the $20^{\text {th }}$ Century thought of the possibility of making Confucianism a Chinese counterpart to Western Christianity. While Huxley was strictly opposed to any religious attempts to intervene in the field of science, the Chinese, who had never experienced any religion-based restriction on thought, were actually tempted to use artificially-established religion as the means of national unification. Because of missionary activity in China, which stressed positive religious influence on society, Chinese intellectuals understood Christianity as a powerful and essential part of Western civilization, which helped its progress. The idea was however never formally put into practise in the imperial China of $19^{\text {th }}$ Century.

\subsection{Evolution and the Utopian Concept of Great Harmony}

What was further appealing for Chinese audience was also Spencer's concept of gradual social progress through certain stages; from chaos to order, from lower states to higher ones. Similar gradual self- and social improvement was at the core of Chinese thought since ancient times. The concept of gradual development also meant, that China could still develop and progress from lower state to the higher one, despite having fallen behind. The process of stage development was understood cyclically: degradation of the most developed always threatened all, and the rise of those below was always plausible. While Western powers were on the peak, China saw that in future, it would be China's turn to surpass foreign countries in development and progress. This idea was further reinforced later in $20^{\text {th }}$ Century, when even Western thinkers were inclined to look towards Asia as the source of cultural and spiritual inspiration. China itself did not see its future supremacy only in the field of spirituality (which is, objectively speaking, questionable as both civilizations have both spiritual as well as secular sphere) but in the field of economics, technology and overall development too. Other countries were understood (and sometimes still are) as states which had already reached the peak of their development and cannot but stagnate or devolve in the future, giving China space to grow.

As mentioned above, traditional Chinese thought also had the concept of gradual social development from chaos to order and peace. The highest and most desirable state possible was called 'Great Harmony' datong. It was a stage where competition and struggle were finally overcome and supreme peace and harmony united the whole world; in short, a utopian vision of a world without suffering and struggle. Ancient philosophers also idealised past as the stage far closer to Great Harmony than any present Chinese kingdom. This enabled them to criticise society as slowly degrading from one stage to another. Same as in other cultures, Chinese scholars understood the world as somehow devolving - the ancient (often legendary) empires were the greatest, then there came a less perfect states and then even lesser ones. Even though development in this concept was in opposition to Spencer's evolutionary theory, which stressed progress towards higher forms, the concept stressed the possibility to turn around the degradation at any time into progress toward better states. ${ }^{30}$ The ideal of datong as the highest goal of social development was thus incorporated into evolutionary theory as understood in China at the turn of the $20^{\text {th }}$ Century.

Even though China was oriented primarily toward its own prosperity, in the concept of datong it embraced better future for the entire world. It was a utopia for all humanity. The goal for many Chinese intellectuals was to transform China into a model for the whole world. But to reach it, it became obvious that China would have to first embrace the stage of brutal struggle and competition in order to become equal. Proponents of evolution stated that it was the

\footnotetext{
30 See SHEN, Tsing-song Vincent. 2014. "Evolutionism through Chinese Eyes: Yan Fu, Ma Junwu and Their Translations of Darwinian Evolutionism." ASIANetwork Exchange 22 (1): pp. 49-60.
} 
ignorance of this competition that made China weak and unfit. The problem was that, traditionally, the ideal of datong could not be reached through ruthless competition. Within the concept of datong all people were treated as equals and the idea that some would survive just because of strength, while others would be sacrificed to bring better future of datong, was contradictory to its purest principles. ${ }^{31}$ The acceptance of social Darwinist competition into the utopian world of datong was therefore not easy at all. Chinese thinkers avoided the dilemma by stating that the world in the current state was not prepared for the peaceful state of datong yet and that the contemporary situation called for competing and struggle to improve the world. Datong was still the supreme aim, but evolutionary struggle was the road: evolution was the presumption of the datong state, and datong was the unavoidable end of evolution. ${ }^{32}$

While Europeans such as Huxley discussed the relationship of struggle and ethics between individuals, Chinese intellectuals like Yan Fu debated over competition and national survival. The idea of evolution in China was pragmatically re-evaluated and applied to the most burning question of national survival. Ethical issues were mostly set aside for the time being, as we can observe on the example of newly re-thought traditional concept of datong. Huxley's lecture, which was focused on British social and political experience, could not fully reach Chinese intellectuals as they dealt with other social and political difficulties. Even though the main goal of Huxley's lecture did not touch Chinese audience, the text itself had tremendous impact on Chinese intellectuals at the end of the $19^{\text {th }}$ Century. It was one of the most influential translations of the end of the last Chinese dynasty.

\section{Summary}

The concept of evolution played a key role in the political and social thought of the $19^{\text {th }}$ Century. British biologist Thomas H. Huxley, otherwise a fierce proponent of Darwin's evolutionary theory, was concerned about the consequences of its application to socio-political questions. Instead of accepting evolutionary theory as a principle applicable to civilization, he established his own approach on the difference between society and nature. Huxley accepted the biological base of humankind, but he placed human ethical ideals into sharp contrast with natural laws. He stated that people governed nature not only by skill and intelligence, but also through ethics; and he feared that the application of evolutionary concepts such as competition would mean forgetting the ethical process which formed civilization. Ethics not only brought humankind to its current place, but it would also prevent it from degradation. All human achievements, including ethics, were according to Huxley accomplished in spite of the cosmic process, not according to it. Huxley thus accepted evolutionary theory only within the field of biology, zoology, and geology; his concept was in sharp contrast with Herbert Spencer's popular application of the theory on human society. Huxley stressed that even though people in modern society might still be asserting their own rights and desires driven by their biological needs, their conscience and ethics kept this self-assertion under reasonable control. Ethics was, in short, what made men truly human.

Application of evolutionary theory on society was brought to the attention of many thinkers by the threat of overpopulation, pauperism and other related economical problems accompanying the Long Depression between years 1873-1896. Huxley feared that the stressful economic situation would contribute to the unethical world order based on evolutionary phrases like

\footnotetext{
${ }^{31}$ For more readings, see WANG, Tiangen. 2016. Spread of [Yan Fu's] Tianyanlun at the End of the Qing Dynasty and at the Beginning of Republic. Hefei: Hefei Gongye daxue chubanshe.

32 Ibid., p. 182.
} 
'survival of the fittest'. This phrase did not base morality on ethical ideals as Huxley wanted, but solely on real life social and economic success. If all people, warned Huxley, the impoverished and the rich alike, were not encouraged to behave by ethical ideals, if only harsh struggle for survival was promoted amongst society, men would behave unethically following just their own interests - which, along with the high number of mainly paupers' 'unethically raised' children, would inevitably lead to a less ethical world. And a less ethical world, feared Huxley, would threaten the very roots of society. People could not depend on nature when it came to morality because nature had no moral base. According to Huxley, ethics was the domain of human conscience which enabled men to judge everything as either good or wrong. Ethics kept cosmic processes and selfish self-assertion under control to the benefit of the individual and the whole society as well - it surpassed the natural world of mere survival and it was also much more than a mere cooperation of packs and herds or a primeval instinct of wolves that 'they should not attack one another during the chase. ${ }^{33}$ Ethical behaviour was established by society for evaluating righteousness of one's action: while evil might have gone unpunished in nature, it could be punished within society because of the existence of moral standards. Human society set moral standards, not nature. The maintenance of proper civilized society consequently relied on ethical processes' control over nature. Huxley's aim was a society which would be both strong (to survive in the competition and natural selection) and ethical (to preserve what was essential to humanity). As both components were essential, Huxley refused to do away with any of them, which was exactly what evolutionary ethics of Herbert Spencer did in his eyes.

In China, the Theory of Evolution, as presented by $\mathrm{Yan} \mathrm{Fu}$, was understood as one of the greatest ideas of $19^{\text {th }}$ Century. It was Yan Fu's commented translation of On Evolution which introduced evolution as well as evolutionary ethics to China. The text was so popular that it spread even before its official publication in 1898. Even though the text claimed to be a translation of Huxley's essay, it was far more interested in the universal application of evolutionary theory to society. The Theory of Evolution was immediately dragged into the discussion about national survival of the Chinese empire. The idea of competition between nations and the concept of inevitable progress meant that evolution, as understood by Herbert Spencer, gained immediate approval of vast majority of Chinese intellectuals. It is interesting to realize how much most Chinese embraced social Darwinism and to what extent they perceived poor treatment of Asia by the international forces as a legitimate outcome of their own 'incompetency' and 'unfitness'. Evolution was understood as an ultimate universal principle which could be applied to anything. It led to a general belief that having realized this new universal truth, supported also by traditional Chinese concepts, China would be able to fully understand the world and to improve its own position in it. While Huxley focused on preventing struggle in society, Chinese scholars tried to make the best use of it: in China, the translation of Huxley's essay paradoxically helped to spread evolutionary ethics, the idea Thomas Henry Huxley strongly disapproved of.

\section{References}

BARTHOLOMEW, Michael. 1975. "Huxley's Defence of Darwin.” Annals of Science 32 (6): 525-35. http://www.blc.arizona.edu/courses/schaffer/449/Huxley's\%20Defense\%20of\%20

Darwin.pdf (accessed 7 March, 2017).

BOWLER, Peter J. 1984. Evolution, the History of an Idea. Berkeley: University of California Press.

\footnotetext{
${ }^{33}$ HUXLEY, Thomas Henry. 2015. Evolution and Ethics. London: Forgotten Books. p. 10.
} 
HELFAND, Michael S. 1977. “T. H. Huxley's 'Evolution and Ethics': The Politics of Evolution and the Evolution of Politics." Victorian Studies 20 (2): 159-77. http://www.jstor.org/stable/3826154 (accessed 6 February, 2017).

HUXLEY, Thomas Henry. 2015 (reprint). Evolution and Ethics. London: Forgotten Books.

HUXLEY, Thomas Henry. 1894. "Evolution and Ethics Prolegomena.” In Evolution and Ethics and Other Essays, 1-45. London: Macmillan and CO. https://ia802702.us.archive.org/31/items/evolutionethicso00huxl/evolutionethicso00huxl.pdf (accessed 15 February, 2017).

HUXLEY, Thomas Henry. 1894. "The Struggle for Existence in Human Society.” In Evolution and Ethics and Other Essays, 195-236. London: Macmillan and CO. https://ia802702.us.archive.org/31/items/evolutionethicso00huxl/evolutionethicso00huxl.pdf (accessed 15 February, 2017).

FREEMAN. Derek. 1974. "The Evolutionary Theories of Charles Darwin and Herbert Spencer." Current Anthropology 15 (3): 211-37. http://www.jstor.org/stable/

2740899?seq=1\#page_scan_tab_contents (accessed 6 February, 2017).

LOMOVÁ, Olga. 2014. "Liang Qichao v roce 1902: Přeměna Číny v silný a moderní stát za pomoci nového myšlení [Liang Qichao in 1902: The transformation of China into a strong and modern nation with the help of new thought]." Český časopis Historický 112 (2): 197-226.

OTTE, Thomas G. 2007. The China Question: Great Power Rivalry and British Isolation, 1894-1905. New York : Oxford University Press.

PRICE, Don C. 2004. 'From Might to Right: Liang Qichao and the Comforts of Darwinism in Late-Meiji Japan. ' in FOGEL, Joshua A. (ed.). The Role of Japan in Liang Qichao's Introduction of Modern Western Civilization to China. China Research Monograph 57. Berkeley, Calif: Institute of East Asian Studies, University of California Berkeley, Center for Chinese Studies.

SCHRECKER, John E. 1971. Imperialism and Chinese Nationalism: Germany in Shantung. Cambridge, MA: Harvard University Press.

SCHWARTZ, Benjamin I. 1964. In Search of Wealth and Power: Yen Fu and the West. Cambridge: Belknap Press of Harvard University Press.

SCOTT, David. 2008. China and the International System, 1840-1949 : Power, Presence, and Perceptions in a Century of Humiliation. Albany, NY: State University of New York Press.

SHEN Tsing-song Vincent. 2014. "Evolutionism through Chinese Eyes: Yan Fu, Ma Junwu and Their Translations of Darwinian Evolutionism." ASIANetwork Exchange $22 \quad$ (1): 49-60. http://www.asianetworkexchange.org/articles/abstract/10.16995/ane.135/ (accessed 9 Novem-ber, 2017).

SMILES, Samuel. 1968. Self-Help : The Art of Achievement Illustr. by Accounts oh the Lives of Great Men. London: Sphere Books.

WANG Fansen. 1997. "Evolving Prescriptions for Social Life in the Late Qing and Early Republic: From Qunxue to Society." In Imagining the People: Chinese Intellectuals and the Concept of Citizenship, 1890-1920, Studies on modern China, 258-78. Armonk, N.Y: M.E. Sharpe.

WANG Tiangen. 2016. 《天演论》传播与清末民初的社会动员 [Spread of [Yan Fu's] Tianyanlun at the End of the Qing Dynasty and at the Beginning of Republic]. Hefei: Hefei Gongye daxue chubanshe. 